Пугінська В. В., аспірант

Чиняк В. В., аспірант

Карабінюк М. М., асистент

Ужгородський національний університет

м. Ужггород, Закарпатська область, Украӥна

DOI: https://doi.org/10.30525/978-9934-26-028-5-13

\title{
ПЕРСПЕКТИВИ РОЗВИТКУ ТУРИСТИЧНОЇ СФЕРИ ЗАКАРПАТСЬКОЇ ОБЛАСТІ ШЛЯХОМ ОПТИМІЗАЦЇ̈ ДІЯЛЬНОСТІ ЛІСОВОГО СЕКТОРУ РЕГІОНУ
}

Закарпатська область - один із регіонів України, що має найбільший потенціал розвитку лісового господарства та ведення лісогосподарської діяльності. Саме ліси є одним із природних багатств краю, вони відіграють ключову роль у виконанні водозахисних та кліматорегулюючих функцій, розширюють перспективи розвитку рекреації і туризму в регіоні. Лісистість Закарпатської області становить 52\%, що є найбільшим показником між областями Карпатського регіону і майже утричі перевищує значення відповідного показника в Україні $(17,7 \%)$ [9].

На даний момент лісогосподарські підприємства області проводять свою діяльність за обмежених фінансових ресурсів та повинні самостійно шукати варіанти для отримання додаткового доходу, щоб забезпечити можливості інтенсивного розвитку та досягнення поставлених цілей. Саме реалізація рекреаційного лісокористування дозволить забезпечити можливості отримання додаткового прибутку як лісовими підприємствами так i, крім того, сприятиме розвитку туристичної сфери Закарпаття.

Варто зазначити, що протягом останніх років спостерігається зростання значення лісу як ресурсу галузі відпочинку, його значно ширшого використання у рекреаційних цілях. На даний момент в Україні рекреаційно-оздоровчі ліси становлять 15\% від їх загальної площі [3].

Рекреаційні функції лісів Закарпатської області є диверсифікованими і забезпечують відвідувачів/туристів цілим 
комплексом різноманітної діяльності. За цілями цю діяльність можна розділити на окремі групи:

Таблиця 1

Рекреаційна діяльність, що може здійснюватися в лісах

\begin{tabular}{|c|c|c|c|c|}
\hline \multicolumn{5}{|c|}{ Рекреаційні функиї лісів } \\
\hline $\begin{array}{c}\text { Рекреа- } \\
\text { ційно- } \\
\text { оздоровча } \\
\text { діяльність }\end{array}$ & $\begin{array}{c}\text { Рекреаційно- } \\
\text { спортивна } \\
\text { діяльність }\end{array}$ & $\begin{array}{c}\text { Рекреаційно- } \\
\text { туристична } \\
\text { діяльність }\end{array}$ & $\begin{array}{c}\text { Рекреаційно- } \\
\text { утилітарна } \\
\text { діяльність }\end{array}$ & $\begin{array}{c}\text { Рекреаційно- } \\
\text { пізнавальна } \\
\text { діяльність }\end{array}$ \\
\hline & & Подорожі & & Здійснюється \\
Зниження & & і походи, & & в дендраріях, \\
нервового & Заняття & організовані & Збирання \\
напру- & з метою & саних \\
ження та & спортом & пізнання & гриб, ягід & людина може \\
втоми & & природи та & & $\begin{array}{c}\text { підвищити свій } \\
\text { рівень знань }\end{array}$ \\
\hline
\end{tabular}

Джерело: розроблено авторами на основі [11]

Лісові масиви на території області розташовані в основному в гірській частині, на яку припадає 80\% території [1] (північні та північно-східні території новоутворених районів Закарпаття). Одною із характеристик лісових масивів краю $є$ їх атракторність, а естетичний вплив лісу формує позитивні емоції та асоціації. Незважаючи на широкий туристично-рекреаційний потенціал Закарпаття, процес його становлення й інтенсивність освоєння перебуває на початковій стадії.

Основною проблемою розвитку лісів в рекреаційне середовище залишається недостатньо розвинута інфраструктура індустрії гостинності, що значно впливає на туристичний потік. Адже тутешні дестинації не витримують конкуренції із сусідніми областями (Львівською, Івано-Франківською тощо) [11] саме через відсутність поміркованої цінової політики та співвідношення понять «ціна-якість».

Проте протягом 2015-2019 рр. спостерігалася тенденція до поступового збільшення кількості туристів в Закарпатській області. Це явище мало позитивний ефект для економіки. 
Що стосується прибутків, то вони прямо пропорційно до кількості туристів стабільно зростали в період із 2015 до 2019 року (рис. 1).

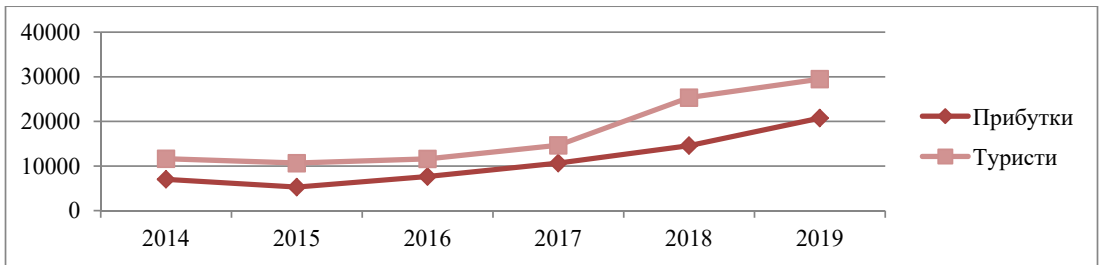

Рис. 1. Обсяги реалізованої продукції туристичної діяльності (тис. грн) та кількість туристів у Закарпатській області (тис. осіб)

Джерело: розроблено авторами на основі [4-9]

Однак такі тенденції не збереглися у зв'язку 3 початком впровадження на початку 2020 року заходів щодо запобігання розповсюдження коронавірусної інфекції SARS-CoV-2.

Для того, щоб не втрачати стабільний рівень прибутку, туристичній сфері Закарпаття доцільно було б переорієнтовуватися саме на перевагу у вигляді різноманітних рекреаційних функцій лісових масивів області. Рекреаційні функції лісів $€$ привабливими не лише для іноземних відвідувачів/туристів, але й для внутрішнього туризму, тому не зважаючи на те, що зовнішній туристичний потік на разі майже відсутній, саме до Закарпаття значно збільшився притік українських туристів.

Цю ситуацію можна використати для налагодження інфраструктури та кластерного зв'язку між різними туристичними об'єктами, які знаходяться в лісах Закарпаття і мають велику природну, культурну та історичну цінність. Також важливою для розвитку індустрії гостинності $\epsilon$ підготовка висококваліфікованих кадрів, які будуть професійно виконувати свої обов'язки та покращувати туристичний імідж регіону. Важливо пам' ятати, що важливою умовою при перетворенні лісів в рекреаційне середовище $є$ збереження їх самобутності та естетичної цінності [2]. 
Можливі варіанти оптимізації діяльності лісового сектору в галузі рекреаційного лісокористування та їх вплив на перспективи розвитку туристичної сфери наведені на рисунку 2.

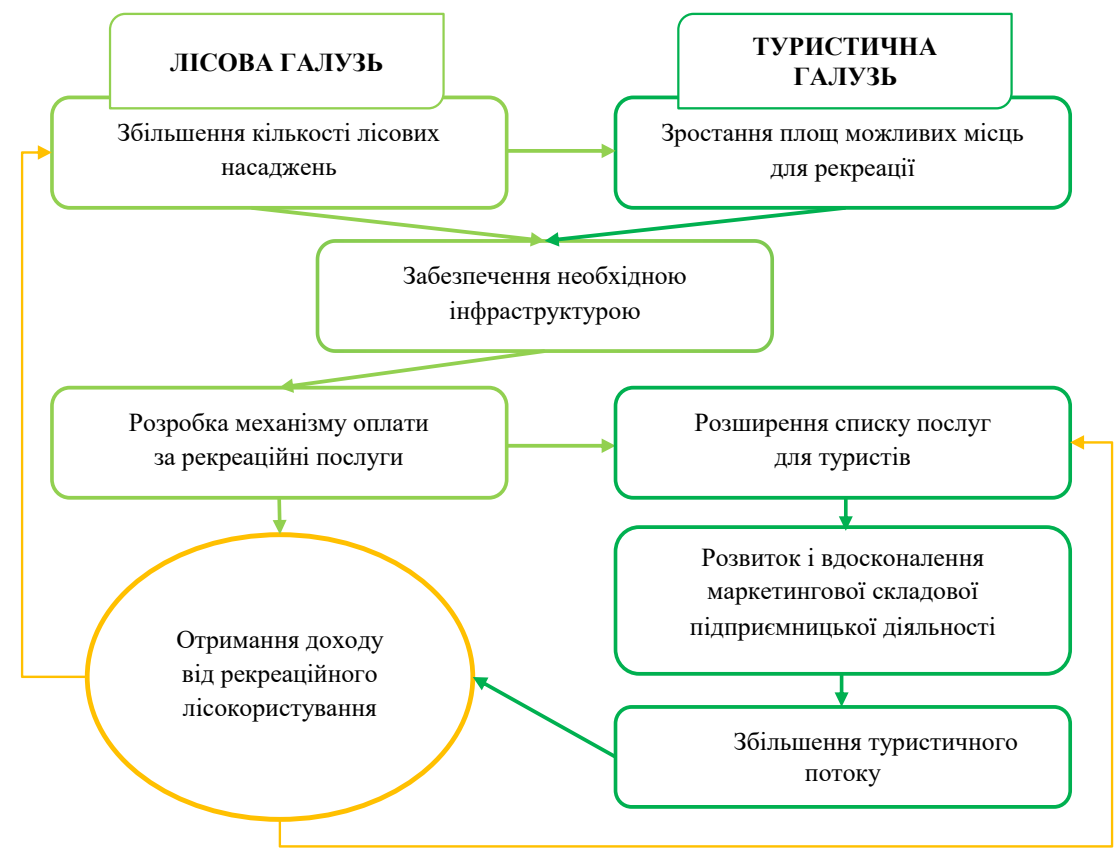

\section{Рис. 2. Вплив рекреаційного лісокористування на лісову та туристичну галузі}

Джерело: розроблено авторами

Отже, обидві галузі знаходяться у тісному взаємозв'язку, де розвиток одної майже неможливий без розвитку іншої. Тісна співпраця лісового та туристичного секторів сприятиме як зростанню їх дохідності, так і розвитку потенціалу Закарпатської області загалом.

\section{Література:}

1. Лісове господарство. URL: https://zakarpatlis.gov.ua/napryamky-diyalnosti/lisove-hospodarstvo. 
2. Михайлюк I.I. Тези доповідей Міжнародної науково-практичної конференції «Управління економічними процесами: сучасні реалії і виклики» (м. Мукачево, 22-23 березня 2017 р.). Мукачево : МДУ, 2017. 407 с.

3. Пугінська В.В., Чиняк В.В. Рекреаційне лісокористування як перспектива розвитку лісової галузі в Україні. Актуальні проблеми використання потенціалу економіки країни: світовий досвід та вітчизняні реалії: матеріали V Міжнародної науково-практичної конференції (м. Дніпро, 28 листопада 2020 р.). Частина 1. Дніпро : ПДАБА, 2020. С. 115-117

4. Статистичний щорічник України за 2014 рік / за ред. I.М. Жук. Київ : Державна служба статистики України, 2015. 586 с.

5. Статистичний збірник «Регіони України» 2015 частина II / за ред. I.M. Жук. Київ : Державна служба статистики України, 2015. 681 с.

6. Статистичний щорічник України за 2016 рік / за ред. I.Є. Вернера. Київ : Державна служба статистики України, 2017. 611 с.

7. Статистичний збірник «Туристична діяльність в Україні у 2017 році» / відп. за випуск О.О. Кармазіна. Київ : Державна служба статистики України, $2018.90 \mathrm{c}$.

8. Статистичний збірник «Регіони України» 2019. Частина I / за ред. I.Є. Вернера. Київ : Державна служба статистики України, 2019. 309 с.

9. Україна в цифрах. 2019: стат. зб. Держ. ком. статистики України. Київ, 2020. 46 c. URL:http://www.ukrstat.gov.ua/druk/publicat/kat_u/2020/zb/07/zb_Ukra ine $\% 20$ in\%20figures_u.pdf.

10. Фоменко Н.В. Рекреаційні ресурси та курортологія : підручник / Н.В. Фоменко. Київ : Центр навчальної літератури, 2007. 312 с.

11. Чиняк В.В., Пугінська В.В. Стан туристичної діяльності в областях Карпатського регіону України. Сучасні тенденції розвитку індустрії гостинності : міжнародна науково-практична конференція, 26-27 листопада 2020 р. : матеріали конференції. Львів : ЛДУФК, 2020. С. 295-297 